PRACTICE PAPER

Volume 2012 Number 9

\title{
Measuring the 'Inclusivity' of Inclusive Business
}

Elise Wach

April 2012 


\section{About IDS}

The Institute of Development Studies is one of the world's leading charities for research, teaching and communications on international development. Founded in 1966, the Institute enjoys an international reputation based on the quality of its work and the rigour with which it applies academic skills to real world challenges. Its purpose is to understand and explain the world, and to try to change it - to influence as well as to inform.

IDS hosts six dynamic research programmes, five popular postgraduate courses, and a family of worldclass web-based knowledge services. These three spheres are integrated in a unique combination - as a development knowledge hub, IDS is connected into and is a convenor of networks throughout the world.

The Institute is home to approximately 80 researchers, 50 knowledge services staff, 50 support staff and about 150 students at any one time. But the IDS community extends far beyond, encompassing an extensive network of partners, former staff and students across the development community worldwide.

For further information on IDS publications and for a free catalogue, contact:

IDS Central Communications

Institute of Development Studies

Brighton BN1 9RE, UK

Tel: +44 (0) 1273915637

Fax: +44 (0) 1273621202

E-mail: bookshop@ids.ac.uk

Web: www.ids.ac.uk/ids/bookshop 
IDS PRACTICE PAPER 9

Measuring the 'Inclusivity' of Inclusive Business

Elise Wach

April 2012 
Measuring the 'Inclusivity' of Inclusive Business

Elise Wach

IDS Practice Paper 9

First published by the Institute of Development Studies in April 2012

(c) Institute of Development Studies 2012

ISSN: 2040-0209 ISBN: 978-1-78118-047-1

A catalogue record for this publication is available from the British Library.

All rights reserved. Reproduction, copy, transmission, or translation of any part of this publication may be made only under the following conditions:

- with the prior permission of the publisher; or

- with a licence from the Copyright Licensing Agency Ltd., 90 Tottenham Court Road, London W1P 9HE, UK, or from another national licensing agency; or

- under the terms set out below.

This publication is copyright, but may be reproduced by any method without fee for teaching or non-profit purposes, but not for resale. Formal permission is required for all such uses, but normally will be granted immediately. For copying in any other circumstances, or for re-use in other publications, or for translation or adaptation, prior written permission must be obtained from the publisher and a fee may be payable.

Available from:

Communication Unit

Institute of Development Studies

Brighton BN1 9RE, UK

Tel: $+44(0) 1273915637$

Fax: +44 (0) 1273621202

E-mail: bookshop@ids.ac.uk

Web: www.ids.ac.uk/ids/bookshop

Typeset by Warwick Printing, Leamington Spa, UK. Printed by Nexus, Brighton, UK.

IDS is a charitable company limited by guarantee and registered in England (No. 877338) 


\title{
Measuring the 'Inclusivity' of Inclusive Business
}

\section{Elise Wach}

\begin{abstract}
Summary
'Inclusive Business' has enormous potential to contribute positively to development outcomes. Working through core business models, the 'Inclusive Business' approach requires minimal outside support and can often reach a scale unattainable by most direct development interventions. Take for example, Vodafone's M-PESA service, which has reached more than 18.5 million individuals since 2007 and continues to be a profitable business model (BCtA 2011).

But when is business 'inclusive' and when is it simply business? How does CocaCola's business model in El Salvador contribute more to women's empowerment than its typical approach to selling fizzy drinks? Accurate information about business impacts - direct and indirect, positive and negative - can help practitioners to better identify (and support) the approaches that can most positively contribute to development.
\end{abstract}

This paper analyses some of the current approaches and frameworks for evaluating 'Inclusive Business' impacts. It finds that while they shed light on the complex network of effects that businesses have and the ways in which some firms are attempting to contribute to development, they are unable to provide information about the actual impacts of business activities. More, higher quality, and less partial 'Inclusive Business' evaluations are needed to better enable us to harness the potential for business to contribute positively to development.

Keywords: Inclusive Business; development; impact; monitoring and evaluation (M\&E); causal chain; counterfactual.

Elise Wach, Evaluation and Learning Consultant, focuses on impact assessment, organisational learning and monitoring and evaluation (M\&E). Elise has eight years of experience in business and development and participatory approaches, primarily in Africa and Central America. This paper was written as a dissertation for the IDS MA in Development Studies in 2011 and its publication was funded by the IDS Teaching Team. The author would like to thank Neil McCulloch, Noshua Watson, Henry Lucas, and Susie Page at IDS for their reviews and valuable feedback. 
IDS PRACTICE PAPER 9 


\section{Contents}

Summary, keywords, author note 3

Acronyms 6

1 Introduction 7

2 Determining inclusivity 8

2.1 Existing definitions $\quad 8$

2.2 What constitutes 'inclusive?' The causal chain 9

2.3 How do 'inclusive' practices weigh against 'non-inclusive' practices?

3 How are inclusive business models being evaluated? 13

3.1 M\&E frameworks $\quad 14$

3.2 Impact evaluations 17

3.2.1 INSEAD Economic Footprint 18

3.2.2 Oxfam Poverty Footprint 23

4 Implications of impact evaluations $\quad 25$

5 Conclusions 26

$\begin{array}{ll}\text { References } & 28\end{array}$

\section{Figures}

Figure 2.1 Illustrative causal chain analysis for Nirma detergent

Figure 3.1 Potential income scenarios for Nestle Bienestar participants and non-participants

Table

Table 3.1 Overview of existing M\&E and impact evaluation frameworks for inclusive business

Box

Box 3.1 Counterfactuals vs before and after comparisons 


$\begin{array}{ll}\text { ACrONYMS } \\ \text { BCtA } & \text { Business Call to Action } \\ \text { BEE } & \text { Black Economic Empowerment } \\ \text { BIF } & \text { DFID Business Innovation Facility } \\ \text { CSR } & \text { Corporate Social Responsibility } \\ \text { DFID } & \text { Department for International Development } \\ \text { ERR } & \text { Economic Rate of Return } \\ \text { IBLF } & \text { International Business Leaders Forum } \\ \text { IRIS } & \text { Impact Reporting and Investment Standards } \\ \text { M\&E } & \text { monitoring and evaluation } \\ \text { R\&D } & \text { research and development } \\ \text { SAM } & \text { Social Accounting Matrix } \\ \text { SMEs } & \text { small and medium enterprises } \\ \text { SNV } & \text { Netherlands Development Organisation } \\ \text { UNDP } & \text { United Nations Development Programme } \\ \text { UNEP } & \text { United Nations Environment Programme } \\ \text { USAID } & \text { United States Agency for International Development } \\ \text { WBCSD } & \text { World Business Council for Sustainable Development }\end{array}$




\section{Introduction}

The concept of 'business fighting poverty' is taking the development community by storm, and it is easy to see why. The concept of 'Inclusive Business,' or achieving development objectives through a core business model (rather than through separate Corporate Social Responsibility (CSR) activities), offers a number of advantages over traditional development approaches. Because the approach is based on profitability, little or no public funding is required, and the activities are likely to continue in the long term (in contrast to fixed-term donor-supported programmes). In addition, businesses often have the potential to reach a scale that is unattainable by most direct development interventions; Vodafone's M-PESA service in East Africa, for example, has reached more than 18.5 million individuals (BCtA 2011).

Because of the advantages of this approach to development, many donors are increasingly supporting 'Inclusive Business' models. The Department for International Development (DFID), United Nations Development Programme (UNDP), and United States Agency for International Development (USAID) have all recently created departments dedicated to supporting 'Inclusive Business' initiatives. At the same time, the private sector is increasingly recognising - with or without the assistance of donor agencies - the benefits of the 'Inclusive Business' approach. Prahalad (2004) drew attention to the potential profitability of direct interaction with the poor (i.e. the 'fortune at the bottom of the pyramid'); and an improved public image as a result of an 'Inclusive Business' approach also brings benefits.

Given the potential scale and scope of such private sector projects and the increasing interest of both donors and businesses, it is important to understand both the direct and indirect impacts of 'Inclusive Business' approaches. This understanding will enable us to better distinguish the difference between 'Inclusive Business' and just plain business so that we as practitioners can better harness the potential for businesses to positively contribute to development.

However, the nature of the projects and stakeholders present a number of obstacles to rigorous impact assessment. Inclusive businesses are generally large-scale with diffuse and widely dispersed impacts, making them difficult to measure under any circumstance. Further, private sector actors generally do not possess experience in 'development' or measuring 'development impacts'.

A number of frameworks have been designed to measure Inclusive Business impacts, including the Business Call to Action (BCtA) Results Reporting Framework, the Oxfam Poverty Footprint, World Business Council for Sustainable Development (WBCSD) Measuring Impact Framework, and the INSEAD Poverty Footprint approach. This paper looks at the ability of these frameworks to measure the impact of Inclusive Business and provide practitioners with accurate information as they move forward with their support to the Inclusive Business approach.

The first section of the paper explores how exactly 'inclusiveness' is defined, with a discussion of existing definitions, the determination of whether a business model results in positive impacts, and issues around weighing positive impacts against 
negatives ones. The second section of the paper analyses the existing monitoring and evaluation (M\&E) frameworks and impact evaluation frameworks being applied to Inclusive Business models. The third section explores the implications of these evaluations, and the last section offers some concluding remarks.

\section{Determining inclusivity}

\subsection{Existing definitions}

Each of the key organisations working in the field of 'Inclusive Business' has its own slightly different definition of what it means when a business (or a particular business model) ${ }^{1}$ is 'inclusive'; however, there seems to be consensus that Inclusive Business entails creating a net positive development impact through an financially profitable business model. DFID's Business Innovation Facility defines Inclusive Business as 'profitable core business activity that also tangibly expands opportunities for the poor and disadvantaged in developing countries' (BIF 2011). Endeva expands the definition slightly, stating that Inclusive Businesses make 'A positive contribution to the development of companies, the local population and the environment' (Gradl and Knobloch 2010: 10). The World Business Council for Sustainable Development (WBCSD) and the Netherlands Development Organisation (SNV) define Inclusive Business as 'An economically profitable, environmentally and socially responsible entrepreneurial initiative' (2011: 13).

There also seems to be consensus about the ways in which business activities can benefit the poor: broadly, 'Inclusive business integrates people living in poverty into the value chain as consumers or producers' (Gradl and Knobloch 2010: 10). The DFID Business Innovation Facility (BIF) report states that business models can 'Engage the poor as employees, suppliers, distributors, or consumers and expand their economic opportunities in a wide variety of ways' (BIF 2011). UNDP states that 'Inclusive Business models include the poor on the demand side as clients and customers, and on the supply side as employees, producers and business owners at various points in the value chain' (UNDP 2008: 2).

However, Ashley (2009: 3 ) is a bit more specific in the types of business models that can have a positive development impact, listing four different types of business models that can be considered 'inclusive':

(i) selling products and services that are 'needed by the poor and have a high development impact' (such as low-cost nutrient-fortified foods),

(ii) large companies that 'take deliberate action to expand development impacts through supply and distribution chains or R\&D [research and development]' (such as SABMiller),

1 Some definitions explicitly focus on business models, some refer to the businesses as a whole, and others refer to business activities in general. This paper covers evaluations of each of these, but an in-depth comparison of the ways in which 'business' is defined is not within the scope of this paper. 
(iii) domestic small and medium enterprises (SMEs) that 'have local economic development as an explicit driver because they are embedded in the local economy', and

(iv) 'social enterprises whose core product is of high social value'.

The concept of mutual benefit also recurs in definitions of Inclusive Business: UNDP states that Inclusive Business models 'Build bridges between business and the poor for mutual benefit' (UNDP 2008: 2), and WBCSD states that Inclusive Business models 'Integrate low-income communities in its value chain for the mutual benefit of both the company and the community' (WBCSD and SNV 2011:13).

In sum, from the above definitions, it appears that Inclusive Businesses can be characterised by being economically viable business models that result in positive impacts for poor people and/or the environment through the integration of poor people 2 into value chains and/or environmentally sustainable practices. But given that even DFID states that 'Virtually any business - not just that which is labelled "inclusive" - can help a country develop, whether through taxes, employment, market expansion, or technology transfer' (BIF 2011: 1), how exactly does one draw the line between inclusive and non-inclusive business models? DFID states that 'inclusive business goes further, in creating new economic opportunities for people living in poverty, perhaps as workers or as consumers of affordable good and services, or as participants in low carbon and climate resilient growth [italics added for emphasis]' (2011: 1), but making this distinction is not always straightforward.

\subsection{What constitutes 'inclusive?' The causal chain}

One of the four types of Inclusive Business models categorised by Ashley (2009: 3) is that of 'Selling products and services that are needed by the poor and have a high development impact'. A frequently cited example of this is Danone yogurt, which was fortified with additional nutrients and sold at lower prices to make it affordable to the poor (Ashley 2009: 3; Garette and Karnani 2010). This seems relatively simple: selling a nutritional yogurt at low prices improves the nutrition status of the poor, and therefore increases their utility. Selling alcohol or cigarettes to the poor, however, 'Diverts expenditures from more essential products such as nutrition and health care' in addition to harming their health (Garette and Karnani 2010), and therefore would not be inclusive.

But is it really this straightforward? Prahalad (2004) argues that it is wrong for outsiders to undermine the choices of the poor, echoing the economic principle that any agreement entered wilfully on the part of both parties serves to increase one's utility. Banerjee and Duflo's (2007) study shows that the poor purchase items

2 This author recognises the plethora of definitions and debates around poverty and 'the poor'. The term 'the poor' was used in Karnani (2007), and in this case study, the author assumes 'the poor' to mean populations of low income. 
such as cigarettes and alcohol because they are bored - there are few sources of entertainment in poor, rural areas. It is easy to argue that wellbeing isn't just about nutrition and health (though these are clearly vital), that non-necessary products do provide intangible benefits to the poor, and that it wouldn't be appropriate to inhibit access to such items on the grounds of income or poverty. However, it would be difficult to argue that selling alcohol and cigarettes to the poor could be classified as 'inclusive'. But would this also apply to a product that doesn't have as many health implications, such as Nirma, a low-quality detergent that causes blisters, ${ }^{3}$ but is sold at a price that makes it financially accessible for low income populations in India? Or what about a product like Coca-Cola?

Many economists would argue that if the poor are indeed informed of the risks and benefits of a product and still decide to purchase it, then by doing so, they are increasing their utility. However, if people aren't informed - as is often the case with the poor - then how does one weigh their opinion against those of external groups (e.g. development agencies, government, etc.) about what might be good for them? Similar to debates about what constitutes 'development' (Chambers 2004), it seems that the distinction between 'inclusive' and 'non-inclusive' business is highly subjective: whether a product or service is 'inclusive' or yields a positive impact is determined based on the norms and values of the individual or agency deciding (a development agency, a business, or the people who are directly affected by the business activity). And, just as in development, what might be seen as producing a positive impact in some situations may not necessarily be considered 'inclusive' in others (Cartwright 2007).

One way to deal with this issue is to analyse the associated 'causal chain' (White 2009) or 'theory of change' (J-PAL 2011). White states that 'The causal chain links inputs to outcomes and impacts... [it] embodies the programme theory (or theory of change) as to how the intervention is expected to have its intended impact' (2009: 8). Such an approach should answer Karlan and Appel's (2011) questions: 'what is the root cause of the problem', and whether 'the "idea" at hand... actually solves the problem'. As an illustration, let's apply the 'causal chain' approach to Nirma detergent. Karnani (2007:102) states that 'We need more products like Nirma' based on the assumption that 'selling inexpensive, low quality products does not hurt the poor (as long as they understand any tradeoffs related to safety) [emphasis added]'.

Applying the causal chain analysis to the sale of Nirma detergent would yield something along the lines of the following (adopted from White, pers comm): 4

3 While literature suggests that Nirma causes blisters, some Indian acquaintances have informed me that while the detergent is not easy on the skin, they have not experienced anything as harsh as blisters.

4 Personal Communication: Nirma Causal Chain (email sent 28 July 2011). 
Figure 2.1 Illustrative causal chain analysis for Nirma detergent

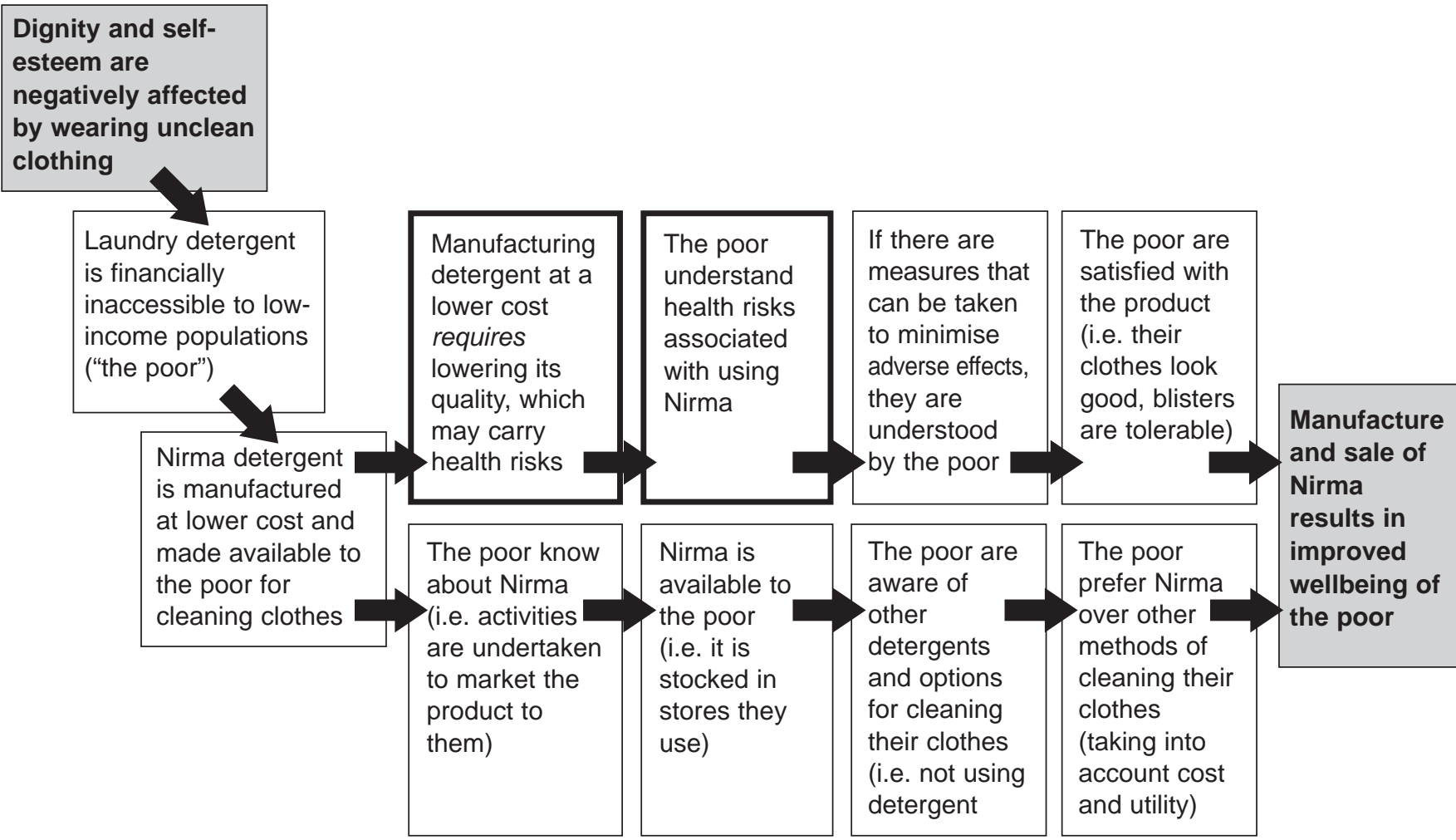

This example illustrates that while thinking through the causal chain, or the 'theory of change' does not enable us to avoid the subjectivity of classifications of 'inclusive' and 'non-inclusive', it does cast light on 'each link (assumption) from inputs to outcomes' (White 2009: 3). Only if all of the links and assumptions are believed to be sound, it would be possible to state that output of selling of Nirma detergent to 1,000 poor people translates to an outcome of increasing the welfare of 1,000 poor people. If a development agency - again, based on governing norms and values - does not agree with the assumption that the poor actually understand the safety risks of the detergent, or that for Nirma to be sold at an affordable price it has to cause health effects, then that agency would not agree that the detergent improves wellbeing and would not consider the business model to be 'inclusive,' even if the detergent were still sold to poor consumers.

Thus, carefully thinking through this causal chain can help determine whether the outputs of a business model (job creation, locally sourced inputs, selling products to the poor, etc.) translate into the desired development outcomes (positive economic, social, and environmental impacts). But there remains the issue of how to weigh potential positive and negative impacts. For example, what if 70 per cent of the poor understand the health risks associated with Nirma's use, but 30 per cent are unaware of them?

\subsection{How do 'inclusive' practices weigh against 'non-inclusive' practices}

First, it is important to recognise that no business model can avoid negative impacts: even the most pro-poor enterprises will inevitably have some negative 
side effects, despite the efforts of management to avoid them. In fact, when businesses try to ensure that all of their impacts are positive, they can run to what Garette and Karnani (2010) term as the 'Multiple Objectives Trap'. In its high-nutrient, low-cost yogurt, for example, Danone attempted to be very ambitious with its environmental impact, which compromised the viability of the business model. As a result, the business was forced to abandon the use of environmentally-friendly packaging and waste management in order to keep the business model afloat (Karnani 2007). Thus, given that one of the key characteristics of an 'Inclusive Business' model is profitability or mutual benefit (UNDP 2008; WBCSD 2011), businesses - and the development agencies supporting them - need to accept that, in order to ensure economic viability, there are limits to the development objectives they can achieve, and the negative impacts they can avoid.

Even approaches as seemingly simple as locally sourcing inputs can have negative impacts. The Oxfam report states that 'Local sourcing can bring value to both companies and poor communities' and recommends that corporations 'foster opportunities for local businesses to supply necessary goods and services that benefit the community and the business' (Oxfam America et al. 2011: 42). But as Born and Purcell (2006) point out, there is nothing inherently good or inherently bad about sourcing 'locally'. While local sourcing could reduce environmental impact through reducing the need to transport goods, and could benefit local economies, there will inevitably be negative impacts of this change: notably, to the 'non-local' suppliers who will likely experience a significant decrease in the demand for their product or service. And if a large firm implements a strict policy of only sourcing locally, it has the potential of reducing competition between local and non-local suppliers, thus reducing one of the key drivers of improvements in efficiency and quality of products and services. There's also the issue of how 'local' is defined, and by whom.

A critical issue here is who determines how the positive impacts weigh against the negative impacts, and how. In its analysis of the Manila Water Company business model, the United Nations Environment Programme (UNEP) acknowledges that not all impacts can be given equal weight: 'In some cases one negative impact could be enough to irreparably damage a company, outweighing the sum of all benefits' (UNEP 2009: 55). UNEP goes on to determine that the benefits provided by The Manila Water Company outweigh the costs. But as with the determination of what constitutes 'inclusive', this is highly subjective. UNEP viewed the provision of water, economic opportunities, tax revenue generated by Manila Water Company, as outweighing the negative livelihoods and wellbeing implications of the Laiban Dam on indigenous groups and local communities; the people living in those communities, however, likely have a different opinion. Beauty (or 'net positive impact') is in the eye of the beholder.

While it is this author's view that both 'inclusiveness' and 'net impact' should be determined by those who are most directly affected by the business, along the lines of the 'Ask Them' approach to determining 'good change' proposed by Chambers (2004), it is also recognised that for a variety of reasons, in practice it is likely the development agency or the most vocal stakeholders - be they government or business leaders - who will ultimately make these determinations. 
Again, while subjectivities may be impossible to avoid, this is another area in which thinking through the causal chain of a business model can help make clear which assumptions are being made, and by whom. And while the determination is subjective, it should be based on a comprehensive understanding of all of the impacts - both positive and negative - of the business model, or at least as many as can be realistically measured.

Based on the above discussion, in order to evaluate 'Inclusive Business' models, it is necessary to

(a) conduct a causal chain analysis to determine how the outputs of a business model are intended to link to desired outcomes,

(b) capture all outputs (or as many as possible) of the proposed business model, both positive and negative, and

(c) determine and make clear who makes the judgement as to what is 'inclusive'.

With this logic in mind, the paper will now turn to an analysis of the frameworks which have been proposed for monitoring, evaluating, and measuring the impact of Inclusive Business models to determine the extent to which they assist us in identifying a business activity as 'inclusive'.

\section{How are inclusive business models being evaluated?}

Numerous frameworks have been proposed to monitor, evaluate, and assess the impact of 'inclusive' business models. To name a few, there is the BCtA Results Reporting Framework, the DFID BIF framework, the USAID and Rockefeller Impact Reporting and Investment Standards (IRIS) framework, the Oxfam Poverty Footprint Methodology, the INSEAD Economic Footprint approach, and the WBCSD Measuring Impact Framework. These can be classified into two broad categories: monitoring and evaluation (M\&E) frameworks, and impact evaluation frameworks.

In this paper we identify M\&E frameworks as those primarily intended to track inputs and assess outputs, often as compared to target objectives (e.g. number of schools constructed during a programme), while impact evaluation frameworks are those designed to determine the impacts or outcomes of a programme (e.g. changes in student performance as a result of a programme). Both types of evaluation methodologies are necessary and each has its specific uses and limitations. Kandhker et al. (2010) argue that they are 'complementary, rather than substitutes'. Table 3.1 summarises some of the existing frameworks for evaluating business practices which will be discussed in the following sections. Due to space limitations, this paper will not examine all of the existing frameworks but will rather focus on those which are most frequently employed and/or referred to in the Inclusive Business community. 
Table 3.1 Overview of existing M\&E and impact evaluation frameworks for inclusive business

\begin{tabular}{|c|c|c|c|}
\hline Framework & Type & Description & $\begin{array}{c}\text { Case study } \\
\text { examples }\end{array}$ \\
\hline $\begin{array}{l}\text { BCtA Results } \\
\text { Reporting } \\
\text { Framework }\end{array}$ & $M \& E$ & $\begin{array}{l}\text { An M\&E framework for businesses to report on } \\
\text { their activities using fixed indicators; annual } \\
\text { reporting is required for BCtA membership. }\end{array}$ & $\begin{array}{l}\text { Cadbury } \\
\text { Cocoa } \\
\text { Partnership }\end{array}$ \\
\hline $\begin{array}{l}\text { INSEAD } \\
\text { Economic } \\
\text { Footprint }\end{array}$ & $\begin{array}{l}\text { Impact } \\
\text { Evaluation }\end{array}$ & $\begin{array}{l}\text { Uses a Social Accounting Matrix, Input-Output } \\
\text { tables, and Economic Rate of Return models to } \\
\text { analyse direct, indirect and induced impacts; } \\
\text { has a heavy economics focus but also claims to } \\
\text { evaluate social and environmental impacts. }\end{array}$ & $\begin{array}{l}\text { Unilever } \\
\text { South Africa }\end{array}$ \\
\hline $\begin{array}{l}\text { Oxfam Poverty } \\
\text { Footprint }\end{array}$ & $\begin{array}{l}\text { Impact } \\
\text { Evaluation }\end{array}$ & $\begin{array}{l}\text { A methodology for impact evaluation based on } \\
\text { five research areas (value chains, macroeconomy, } \\
\text { institutions and policy, social implications of } \\
\text { environmental practices, and product } \\
\text { development and marketing). Used on a case- } \\
\text { by-case basis; not intended to enable systematic } \\
\text { comparisons between firms. }\end{array}$ & $\begin{array}{l}\text { Coca-Cola/ } \\
\text { SABMiller in } \\
\text { El Salvador } \\
\text { and Zambia }\end{array}$ \\
\hline $\begin{array}{l}\text { BIF M\&E } \\
\text { System }\end{array}$ & $M \& E$ & $\begin{array}{l}\text { An M\&E framework which uses some standard } \\
\text { indicators and allows companies to add in their } \\
\text { own; entails reporting at the beginning and } \\
\text { completion of the project, and } 12 \text { months after } \\
\text { completion. }\end{array}$ & $\begin{array}{l}\text { None } \\
\text { available at } \\
\text { this time } 5\end{array}$ \\
\hline $\begin{array}{l}\text { Impact } \\
\text { Reporting and } \\
\text { Investment } \\
\text { Standards } \\
\text { IRIS }\end{array}$ & $M \& E$ & $\begin{array}{l}\text { A reporting framework with fixed indicators which } \\
\text { claims to measure social and environmental } \\
\text { impact, but is more accurately a tool for enabling } \\
\text { investors to compare enterprises; reporting } \\
\text { protocols are determined case-by-case. }\end{array}$ & $\begin{array}{l}\text { KL Felicitas } \\
\text { Foundation, } \\
\text { California } \\
\text { (Investment } \\
\text { Portfolio) }\end{array}$ \\
\hline $\begin{array}{l}\text { WBCSD } \\
\text { Measuring } \\
\text { Impact } \\
\text { Framework }\end{array}$ & M\&E & $\begin{array}{l}\text { A guide for 'measuring impact' which allows } \\
\text { companies to choose their own indicators and } \\
\text { to identify which impacts of the business model } \\
\text { to measure. }\end{array}$ & $\begin{array}{l}\text { Nestle } \\
\text { Bienestar en } \\
\text { Casa }\end{array}$ \\
\hline
\end{tabular}

\subsection{M\&E frameworks}

The majority of the frameworks proposed for the evaluation of Inclusive Business models (including the BCtA, BIF, IRIS, and WBCSD frameworks) can be classified as M\&E Frameworks. They use indicators to track inputs and outputs over time, which provides essential information for understanding whether a business model or programme is meeting its targets. Typically, 'M\&E systems are designed to address compliance - the 'did they do it' question... Did they undertake and complete the agreed activities? Did they deliver the intended outputs (the products or services to be produced)?' (Kusek and Rist 2004: 15).

M\&E systems provide essential data for tracking progress (i.e. enabling stakeholders to understand if the programme or business model is achieving its targets in a timely manner) and showing whether business, governments, or

5 BIF case studies are anticipated to become available in the third year of the initiative, beginning in July 2013. 
donors did what they were supposed to do with their resources. As such, and also because they are relatively straightforward and less resource-intensive in comparison to impact evaluations, M\&E systems are much more commonly used than impact evaluations. But while M\&E frameworks are extremely useful and almost always necessary, by their nature they are incapable of determining whether inputs and outputs result in desired outcomes, and capturing all impacts of a business model. In addition, by their nature, they are incapable of attributing impacts to the business model.

In M\&E frameworks, objectives are typically translated into performance indicators - either predefined and applied to many projects, or tailored to a specific project or business model - for which data is collected to compare actual results to targets (Kusek and Rist 2004: 14). While the use of predefined indicators offers a number of advantages - such as the ability to aggregate results across a variety of projects and the facilitation of the M\&E process for businesses which are not familiar with development issues, predefined indicators are not based on a causal chain analysis and do not always capture all key outputs.

The BCtA framework uses predefined indicators (e.g. 'number of units sold' and 'number of individuals reached by a product or service' (BCtA 2010) to measure the outputs of Inclusive Business models. It takes for granted that progress towards these indicators will result in positive development outcomes regardless of the context. The framework assumes, for example, that hiring or selling a product to a large proportion of women results in a positive change for those women and for society; however, as discussed above, it is necessary to undertake an analysis of the 'causal chain' in order to determine whether outputs (such as selling stoves to women) will result in the desired outcomes (improved wellbeing of women). The use of predetermined indicators does not allow this. While enabling businesses or development agencies to choose their own indicators based on the project may help address this issue, it does not always mean that a 'theory of change' is taken into account. A business could just as easily identify an indicator (e.g. number of units sold, number of people accessing microfinance, or number of trainings conducted) based on mainstream development interventions without actually assessing the needs on the ground and whether their business model is enabling people to meet those needs.

Another issue with M\&E frameworks is ensuring that all key outputs - both positive and negative - are captured (Kusek and Rist 2004: 74). Frameworks which enable businesses to choose their own indicators present the risk of underreporting of negative impacts. Businesses, with profit maximisation as a primary concern (Friedman 1970), and even development agencies, with donor relations and fundraising as key priorities, naturally have a tendency to focus more on the outputs that they anticipate to be positive and leave out indicators that may signpost a lack of progress - or negative consequences - for fear that exposing negative impacts could affect their profits or future funding. ${ }^{6}$

6 This is particularly true for evaluations which are to be made publicly available. This author recognises that some development agencies and businesses are interested to know their negative impacts and use internal evaluations to assess them. 
The WBCSD Measuring Impact Framework, for example enables businesses to identify what aspects of the business they would like to measure (WBCSD 2008: 25). In the application of the WBCSD framework to Nestle's Bienestar en Casa business model, the nutritional impact on households that increased their consumption of Nestle products as a result of the business approach was not considered, despite the fact that the business model was intended to promote the consumption of 'nutritional food' (SNV and WBCSD 2011). Given the inappropriate promotion of 'nutritional' products by Nestle in the past (Palmer 2009), it would seem imperative to include an analysis of the nutritional and health impacts of the programme in such an evaluation. The report also neglects to consider the product's environmental (e.g. resources used in production and distribution) and economic impacts (e.g. how household spending was affected by the increased purchase of Nestle products, or what other products - possibly locally manufactured goods - might have suffered drops in sales as a result).

While predetermined indicators could help avoid the problem of businesses being selective about which outputs to report, even frameworks that adopt this approach run the risk of outputs - both positive and negative - being overlooked. In applying the BCtA framework to a business model such as Danone's low-cost high-nutrient yogurt, for example, relevant indicators could include (a) the number of units of yogurt sold, (b) the income of employees directly hired by the lead company, (c) the number of women that received training, and (d) the cost savings versus purchasing another product (BCtA 2010: 21). However, the BCtA framework includes no indicators which might reflect other positive impacts such as, for example, improved nutrition status of household members as a result of the product, one of the major objectives of the programme (Garette and Karnani 2010). While it could be assumed that in such a situation, either the business or BCtA would add in an appropriate indicator in order to capture that central positive aspect of the programme, it is probably much less likely that an indicator would be added to capture potential negative effects. Regarding environmental impact, for example, the framework does not provide space for a business to analyse or report on the environmental impacts resulting from the distribution of the product or the manufacture or disposal of product packaging.

Thus, the use of both predetermined indicators and tailored indicators can result in overlooking both positive and negative outputs; the extent to which positive or negative outputs are measured depends on who is choosing the indicators. The use of a causal chain could help identify appropriate indicators to capture both positive and negative outputs, but there still lies a third limitation of M\&E frameworks: the inability to distinguish whether changes experienced can be attributed to the business model.

Typically, M\&E frameworks measure progress through comparing indicator measurements to the situation that existed before the programme (i.e. 'before and after' measurements), and the M\&E frameworks proposed for Inclusive Business are no exception. However, a comparison of outcomes from before and after a programme does not enable us to know if the change is a result of the business model, or provide an accurate assessment of the magnitude of the change (CGD 2006; White 2007; Ravallion 2001). In the case of the Nestle Bienestar en Casa programme, the monthly income of women distributors was reported to have increased by 7 per cent during the programme as a result of increased sales. But 
without knowing how the income of the rest of the community changed over the same period of time, it is impossible to know whether these women are actually better off, by how much, and why: it is possible that the incomes of similar women in the area stayed the same during that period, as is implied by the report (Scenario 1 in Box 3.1), but it is also possible that incomes of all women in the area increased by about 7 per cent (e.g. as a result of increasing food prices), and the net effect of the programme was zero (Scenario 2). It is also possible that the average incomes of similar women had decreased during this time period due to an economic downturn, in which case the increase in the incomes of the women distributors would have actually been more than 7 per cent (Scenario 3). Or the incomes of non-participant women may have even increased by more than 7 per cent during that time, in which case the Bienestar en Casa participants would be worse off than their counterparts (Scenario 4).

\section{Box 3.1 Counterfactuals vs before and after comparisons}

\section{Figure 3.1 Potential income scenarios for Nestle Bienestar participants and non-participants}

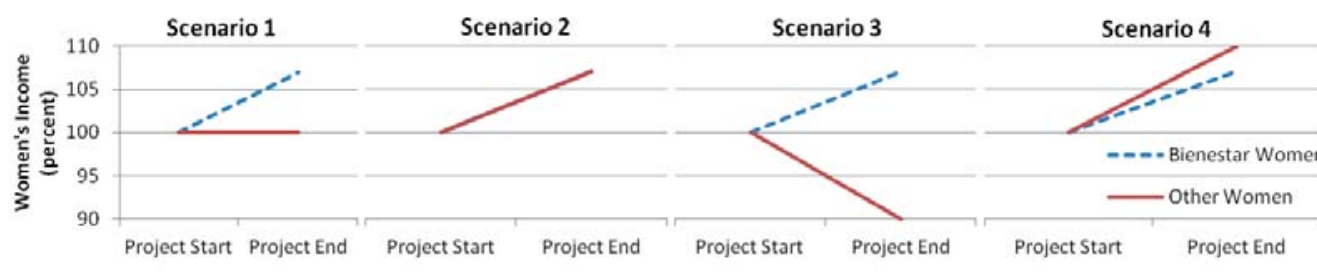

This figure illustrates the importance of understanding what might have happened in the absence of an Inclusive Business model in order to fully understand its impacts.

A similar example is provided in Gertler et al. (2011:41).

It is this issue of understanding the 'situation a participating subject would have experienced had he or she not been exposed to the program' (Kandhker et al. 2010: 7) that distinguishes impact evaluations from M\&E. Thus while frameworks such as the BCtA framework and the WBCSD Measuring Impact Framework provide useful insight into some of the potential outputs of the business model, they do not actually 'measure impact' as many of them - some more explicitly than others - imply. While measuring outputs is a critical aspect of programme implementation and reporting, it is important to not confuse this with impact assessment. Unfortunately, this confusion is apparent in the Nestle report, which states that "Through the application of the MIF, the Bienestar en Casa Program has been shown to be a "win-win" business model for the food sector involving low-income distributors and consumers' (SNV and WBCSD 2011).

\subsection{Impact evaluations}

While impact evaluations can provide much of the information that M\&E frameworks are not designed to capture, they are often costly, time-intensive, and difficult to 
conduct, which is part of the reason why they are less commonly undertaken. In the case of business models, the challenges are even greater. Tanburn states that the impacts of private sector initiatives are not often measured because 'The goals are very ambitious and the impacts costly to quantify, and systemic change in the private sector as a whole does not lend itself to the mechanistic model of inputsoutputs-outcomes-impacts in conventional thinking; attribution and timing issues are acute' (2008: 3).

According to Kandhker et al. (2010), impact evaluations should be conducted under two circumstances: (i) the programme intervention is innovative and of strategic importance, or (ii) the impact evaluation exercise contributes to the knowledge gap of what works and what does not. Similarly, White (2009) claims that impact evaluations are necessary for pilot programmes, innovative programmes, and representative or important programmes. Given the relatively recent nature of the enthusiasm for 'Inclusive Business' (Ashley 2009), the scale of business models, and the number of new initiatives exhorting private enterprises towards achieving development outcomes through their core business models, the need to evaluate the impact of Inclusive Business models is more than evident. Ashley (2008) also points out that when businesses are being supported by donors, it is particularly important to know how 'Inputs translate into impact, and measure up against other investments of time and resources'.

Two frequently cited approaches to evaluating the impact of Inclusive Business models include the INSEAD Economic Footprint and the Oxfam Poverty Footprint. In his 2008 INSEAD report on Unilever's operations in South Africa, Kapstein claims to answer the question 'What is the overall impact of this enterprise on South Africa's growth and development and on its society and environmental quality?' (2008: 3). Similarly, the Oxfam Poverty Footprint guide claims to 'analyse business impacts on society' (Oxfam International 2009: 3). Given that the findings from evaluation reports which have utilised these methodologies have been used to advocate for the scaling up and/or replication of similar business models, it is important to determine whether these frameworks do effectively measure the impact of businesses.

\subsubsection{INSEAD Economic Footprint}

Kapstein's economic footprint report examining Unilever's operations in South Africa uses a Social Accounting Matrix (SAM), Input-Output tables, and Economic Rate of Return (ERR) models to determine the economic impact of Unilever South Africa, as well as quantitative analysis to provide insight into the 'broader social and environmental impacts' (Kapstein 2008: 3).

The report has been frequently cited as a paragon of the impact evaluation of Inclusive Business: WBCSD states that the report 'Examines the overall impact of Unilever's operations on South Africa's growth and development, and on its society and environmental quality' (WBCSD 2011), and Ellis (2008: 2) claims that the report provides a 'robust assessment of [Unilever's] development impact'. This section seeks to determine whether the INSEAD approach? is successfully able to capture

7 This paper will only analyse the INSEAD approach as applied to Unilever in South Africa. Note the approach has differed slightly in each of its applications to date. 
all major impacts; make sound linkages between outputs, outcomes, and impacts; and establish a counterfactual.

While it is always difficult - and arguably impossible - to capture all of the direct and indirect impacts of a programme or business model (Tanburn 2008), in the case of Unilever, which has served as a major producer and distributor of products from margarine to soap in South Africa for more than 100 years, this task is especially challenging. However, in an attempt to include all of the potential effects of the corporation's operations, Kapstein does not limit his evaluation to only the 'first round' economic impacts of Unilever's operations (the jobs created, capital investments, taxes paid, and effects on immediate suppliers), but also includes an analysis of the second-round (indirect) impacts (the effects of Unilever's expenditures on its 'suppliers' suppliers') and even the third-round (induced) impacts of the company ('the effects generated by the consumption decisions' of the employees of Unilever, its suppliers, and its suppliers' suppliers) (2008: 9). Such a broad study is certainly impressive and not commonly undertaken.

Through analysis at these three levels, Kapstein presents findings about the economic impacts on factors such as private sector investment, household incomes, employment rates, and government revenues (Kapstein 2008: 3). Social and environmental 'impacts' measured include hazardous waste produced, energy consumed, and $\mathrm{CO}^{2}$ emitted. While these findings are certainly useful, there may be other key economic, social and environmental impacts of Unilever that may not have been captured. One member of the Reference Group points out, for example, that the report does not provide any insight into 'How Unilever's activities affect environmental resources such as water, soil, air quality and biodiversity' (Chapple in Kapstein 2008: 66). In terms of 'social impacts,' the report discusses the Corporate Social Responsibility (CSR) initiatives of the corporation, which, while important to recognise, do not tell us anything about the social impacts of Unilever's business models themselves, such as nutritional impacts of the sale of Unilever food products or ways in which gender relations have been affected. Even economic outcomes have been overlooked, such as how household budgets have or have not changed with the purchase of Unilever products.

While it is important to recognise the difficulty of anticipating and measuring all of the potential impacts of a business model, much less an entire firm's operations, it is equally critical to recognise the implications of failing to capture basic impacts. Unilever South Africa's operations could very well have a very positive effect on the factors that were not measured, but it is also possible that the impact may be negative; by only reporting on select outcomes, the report does not succeed in providing a complete picture of Unilever's economic, social and environmental impacts. As Oxfam argues in the Reference Group feedback, '[The report] gives a partial analysis of the data which leads to one-sided conclusions on Unilever's impacts'.

For the outputs on which he did report, Kapstein makes a number of assumptions about the impacts of Unilever's initiatives, which may not all be well founded. Two examples include the assumptions made about the provision of financing to suppliers and the impacts of Unilever products (though similar criticism could be made about many other aspects of Kapstein's report, such as Unilever's progress towards 'Black Economic Empowerment' and 'Environmental Stewardship' 
objectives). Kapstein discusses how Unilever has provided financing to suppliers (2008: 27) and states that 'To the extent that Unilever (or another multinational) provides the supplier with financing, it is actually playing a critical developmental role, in effect providing banking services where they are lacking. In that sense, the company is filling a developmental "gap"' (2008: 27). The statement is made based on assumptions that the provision of financing is needed and that the financial services provided meet those needs. While financing is often a major constraint for businesses, the report does not tell us whether it is a constraint for these suppliers in South Africa. Kapstein does not even mention the number of suppliers that have received financing support from Unilever, much less whether those suppliers experienced improved outcomes as a result of that financing.

In the case of products, Kapstein claims that Unilever's products 'prevent diseases' (in the case of hand-washing with soap) and 'can improve the health of children' (in the case of vitamin-enriched margarine) (ibid.). But again, just because these products have the potential to translate into benefits for their consumers doesn't mean that they have done so. The report does not analyse whether the sale of soap has actually resulted in decreased rates of infectious disease, or whether the consumption of fortified margarine actually translates to improved health or nutrition status. The case of margarine may be less straightforward than that of soap: fortified margarine may have better health implications than unfortified margarine, but that is not to say that margarine is a good food option. In fact, through marketing the product as 'healthy', Unilever could be promoting its consumption at the expense of the consumption of healthier alternatives, which could actually have negative implications for the health of its consumer base.

As Cartwright (2007) argues, what may produce positive impacts in one situation will not necessarily produce them in all situations. While in M\&E reports it can be necessary to make assumptions that certain activities (such as soap production) will result in positive outcomes (such as improved health), simply reporting on company activities and assuming that they are beneficial does not actually tell us about the impact of the business activities, which is presumably the purpose of the report.

\section{An advertisement for Unilever's fortified margarine.}

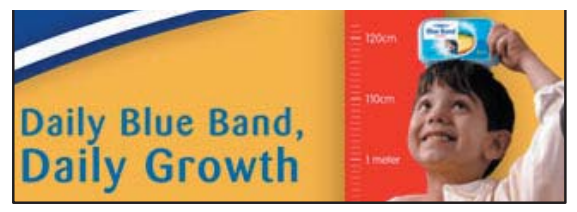

While fortified margarine may be better than unfortified margarine, promoting its consumption as a health product could have negative impacts.

In fact, there appears to be a self-perpetuating cycle of assumptions about impacts. Kapstein states that Unilever provides development benefits by sourcing locally but does not actually conduct an assessment to determine whether sourcing locally is indeed more beneficial than not sourcing locally. However, other scholars and 
practitioners (e.g. Retief 2009) have presumed that such an analysis has been made, and use the Kapstein report to support their argument that sourcing from small, local suppliers results in positive development impacts. Similarly, Kapstein uses Prahalad's (2004) theory (not an actual impact evaluation) to make the claim that selling fortified margarine to the poor will improve their welfare. His 'finding' that Unilever is positively impacting the poor through selling them margarine is then incorporated into M\&E frameworks as a measure of how 'inclusive' businesses are, but at no point was it ever determined - through a causal framework and a counterfactual - that selling fortified margarine at low cost actually had a positive impact on the poor. Perhaps understandably, given that Unilever commissioned the study, Kapstein has a difficult time avoiding an advocacy stance. He reports on good intentions and business policies without any investigation into whether those have translated into outcomes. He states that '[Unilever] seeks to provide them with a variety of health and vitality benefits' (Kapstein 2008: 48, emphasis added). But does 'corporates saying the right things' (Ellis 2008) actually count as 'inclusive' business? As Karlan and Appel (2011) argue, 'More than good intentions are needed to achieve development outcomes'. But assuming that Kapstein had succeeded in capturing all key outputs and outcomes based on a sound theory of change, does his report actually provide information about the impacts of Unilever's operations? In other words, does the report tell us how much better off South Africa is as a result of Unilever's operations?

The report shows that Unilever South Africa has a large economic footprint - it directly or indirectly supports 100,000 jobs and represents 0.8 per cent of total South African employment. But while Kapstein states his intention to examine what would happen if the company 'disappeared from the economic scene' (2008: 7), he does not fulfil this promise. He compares Unilever South Africa's employment effects to those of Coca-Cola in South Africa (from a 1999 study) and a Unilever Indonesia study (which used a different methodology) but does not analyse what the employment effects would be if another company were to take Unilever's place. Just because Unilever supports 100,000 jobs does not mean that those 100,000 people would have been unemployed if it were not for Unilever's existence or further, that they would not be employed in better jobs. It could in fact be that Unilever has created more jobs than would exist in its absence: Ashley (2009: 20) argues that it is not always correct to assume that 'if one company is not filling the gap in the market, then another one will': but this cannot be deduced from Kapstein's report. In terms of Unilever's effect on retailers, the report claims that Unilever has had a positive impact, particularly on small shops that 'rely on wellknown brands such as Sunlight Soap to generate demand from consumers' (2008: 45). However, the report does not look into the counterfactual of other products that retailers might have sold in the absence of Unilever products, or even whether retailers who stock Unilever products experience higher gross sales than similar retailers who do not.

Given its long history and enormous presence in South Africa, determining the counterfactual situation if Unilever did not exist would be an extremely complex and problematic theoretical exercise. While Thorbecke (2000: 39) argues that it is possible to establish a counterfactual on macroeconomic impacts through SAMs 'By using country-specific general equilibrium models reflecting the underlying structure and behaviour of the major actors', he also points out that SAM multiplier 
analyses tend to make a number of 'heroic' assumptions, for example that the business model takes place in a 'Keynesian world in which excess capacity and unused resources prevail and prices remain constant' (2000: 43).

But even if a counterfactual were to be established on the economic 'multiplier' effects throughout the Unilever value chain, simply employing people, sourcing inputs and paying taxes does not necessarily constitute 'inclusiveness.' As Ashley argues, is necessary to determine if 'The way [a business] manages its supply chains differs from those of its competitors, so generating any additional value through its particular business model' (2009: 20). Therefore, perhaps more relevant to the discussion of 'Inclusive Business' is an analysis of what society, the economy, and the environment would look like if Unilever's operations were 'less inclusive.' In addition, establishing the counterfactual for a particular business practice or business model - as opposed to an entire firm - is arguably more feasible. Establishing the counterfactual for a business model could entail comparing the impacts of a firm that has taken a supposedly inclusive approach against the impacts of a firm which has followed the standard approach to same or similar activities. Or, in the case of a firm as large as Unilever South Africa, such a comparison might even be feasible within the firm itself. ${ }^{8}$

Unfortunately, the Kapstein report does not provide information regarding possible counterfactuals for any of Unilever South Africa's practices that might be considered 'inclusive', such as employee capacity-building, the provision of employment to disadvantaged groups, or the provision of financial capital to suppliers. In other words, the report does not indicate whether the welfare levels of Unilever's employees would be different or if productivity might decrease if Unilever were to provide its employees with less comprehensive training. Nor does the report tell us what the employment rates of Blacks might be if Unilever did not follow a Black Economic Empowerment (BEE) strategy; it is possible that Unilever's employment rates (and wages) for Blacks are better than those of similar corporations operating in South Africa, but the report does not enable us to know this. In terms of providing financial services to suppliers, the report does not consider what the outcome might be if Unilever did not provide its potential suppliers with financing. Would another financial mechanism have filled this gap, potentially in a better way? Or would the supplier have gone out of business? Would Unilever have simply sourced from another supplier that did not require financing? And if so, would this have resulted in a less positive development impact?

In short, by not considering counterfactuals, the Unilever South Africa study fails to provide insights into the actual impact of the corporation's practices, despite claims and beliefs that the report actually does so. While it could be that Unilever South Africa's operations have had enormous positive impacts, Kapstein's study simply doesn't enable us to know this. The report is therefore not suitable for informing governments or development stakeholders (such as BIF, UNDP, IBLF,

8 Comparisons of business model impacts could be made using methods such as Propensity Score Matching or structural modelling, which have the potential to provide comparisons when other methods such as randomised control trials are not feasible. 
etc) of the overall impact of Unilever on growth and development - and much less on society and the environment - or which aspects of Unilever's practices can be considered 'inclusive.'

This paper now turns to the Oxfam Poverty Footprint to examine its capacity to evaluate impact.

\subsubsection{Oxfam Poverty Footprint}

The Oxfam Poverty Footprint Methodology has been commonly espoused as an approach to help 'understand and improve poverty impacts' of businesses (Oxfam America et al. 2011: 13). Similar to the Kapstein study, it makes an attempt to capture the full impact of business activities by not just analysing those who are 'directly connected to the business' but also those 'who live in the wider community' (Oxfam International 2009: 11). To date, the tool has been applied to Unilever's operations in Indonesia and more recently to the Coca-Cola/SABMiller value chain in Zambia and El Salvador. Given that the second application of the framework incorporated a number of improvements over the Unilever Indonesia study (Oxfam International 2009: 13), this paper will examine the Coca-Cola/SABMiller value chain report.

The report includes an analysis of potential impacts on livelihoods, empowerment, security and stability, diversity and women's participation, environmental impacts, and enabling policies and institutions. While this represents a laudable improvement over the limited scope of the Kapstein study, many other potentially important impacts are again omitted. For example, the report provides important insights into impacts along the value chain (i.e. the production, distribution and retail of products), as in the Unilever South Africa study, but the impacts of the products themselves are not examined. Thus the nutritional and health impacts of the consumption of Coca-Cola products, one of the most direct and obvious aspects of the business model, are not included. In terms of environmental impact, the report reveals interesting findings about the use of water along the value chain, as well as the effects of product packaging, but does not take into account other potential environmental impacts, such as the ecosystem effects of sugar cane farming or emissions from the manufacture and distribution of products. The Oxfam Poverty Footprint framework provides a much more comprehensive view of the impacts of the Coca-Cola/SABMiller value chain in El Salvador and Zambia, but it could always be argued that other key outcomes - both positive and negative - stemming from the business operations should have been included.

It is important to acknowledge that no study can be fully comprehensive and it is therefore necessary to identify what the most important impacts might be, as well as what impacts are most feasibly measured. While this determination is inherently subjective, there should be an explanation as to why some impacts are examined and others left out, and information about who made that decision. In terms of assessing whether business model outputs result in positive development outcomes, it appears that the framework was able to verify a number of links in the causal chain through consultations with key stakeholders. For example, rather than simply assuming that women's capacity building and access to credit services were key constraints, the evaluation team conducted interviews with stakeholders 
along the value chain to confirm this finding. While it may not seem as though such an assumption would need confirmation, numerous reports have shown that some development programmes which aimed to increase women's employment or access to credit have failed to improve women's wellbeing or social status, due in part to an inadequate analysis of the causal chain (Kabeer 1994; Goetz and Gupta 1996; Bradshaw and Quiros Viquez 2008). In fact, the Oxfam report revealed that while most groups faced constraints in terms of capacity-building and access to credit, this was not the case for women retailers in El Salvador. Findings such as these - and their application - are particularly important as The Coca-Cola Company launches its initiative to 'empower 5 million women entrepreneurs in the Coca-Cola/SABMiller value chain by 2020' through the provision of training and capacity-building activities and financing schemes (Oxfam America et al. 2011: 79). Thus, the Oxfam Poverty Footprint approach does - at least for some outputs - verify the links between business model outputs and outcomes: for certain groups, the provision of credit and training services improves wellbeing. The next question is whether the report adequately explores the impacts of such business activities - what would be the difference if the Coca-Cola/SABMiller value chain never existed, or if 'less inclusive' practices were employed?

As with the Kapstein report, the Oxfam report states the number of jobs created 'directly and indirectly' by the Coca-Cola/SABMiller value chain, but does not provide any assessment that facilitates an understanding as to whether these people would be employed if Coca-Cola/SABMiller did not exist. The claim that the distribution and retail of Coca-Cola products supports 'vital self-employment and employment opportunities' is somewhat misleading in the absence of this counterfactual. For example, Oxfam reports on the number of people supported through employment in the informal sector and states that 'For those at the edge of survival, informal work is often preferable to no work at all' (Oxfam America et al. 2011: 47). However, unemployment is not necessarily the only alternative outcome: it is possible that if these people were not employed informally through the Coca-Cola/SABMiller value chain, they could be earning higher wages or even working in the formal sector. Without a counterfactual it is impossible to know whether the employment generated through the Coca-Cola/SABMiller value chain improves or worsens these people's conditions.

The Oxfam report also fails to provide a counterfactual on the specifically 'inclusive' aspects of Coca-Cola and SABMiller's practices. As an example, the report states that the Coca-Cola/SABMiller business model makes investments 'To enhance the skills, knowledge and capacity of different actors, including the provision of technical assistance and credit programs' (Oxfam America et al. 2011: 53). Not only does the report fail to indicate the number of people that actually benefit from these 'investments', there is no indication that Coca-Cola or SABMiller provide more or better quality services than any other normal business. The report also doesn't explore whether another business or organisation might have provided more of these services if Coca-Cola/SABMiller did not offer them. While it could be that this aspect of the Coca-Cola/SABMiller business model contributes to human capital in ways that would not be provided otherwise, without a counterfactual one cannot rule out the possibility that Coca-Cola and SABMiller actually perform at or below par in this area. 
But while the Oxfam Poverty Footprint approach overlooks some outputs and did not consider a counterfactual - and therefore cannot technically be considered to provide information about the impact of Coca-Cola and SABMiller in El Salvador and Zambia - it does succeed in capturing a more comprehensive package of outputs and in developing a theory of change through consultations with the people directly affected by the businesses, arguably the most important stakeholders. With some improvements, the Oxfam Poverty Footprint could prove to be a very comprehensive and useful tool for measuring the impact of businesses.

\section{Implications of impact evaluations}

The above analysis does not attempt to argue that the business activities evaluated were not actually 'inclusive;' rather, that the evaluations simply don't enable us to know either way. But why is it so important to have rigorous and comprehensive evaluations? According to Ashley et al. (2009), impact evaluations are essential for both 'improving' practices as well as 'proving' impact.

In terms of 'improving' practices, evaluations that do not properly assess impact but are believed to do so could prevent or delay the identification and mitigation of serious problems resulting from a business activity. Kapstein's 2008 report, for example, could permit the Government of South Africa to overlook serious environmental (e.g. water or air quality) or social (e.g. nutrition or livelihoods) impacts of Unilever's operations. On the flip side, inadequate impact evaluations could fail to identify business activities that have enormous development benefits, potentially delaying the expansion or replication ${ }^{9}$ of those beneficial activities.

While operating in a more 'inclusive' way ideally results in a win-win solution for both the business and the communities which it affects, Ellis reminds us that 'In many cases, it may be that operating in a more development-friendly way will increase costs... so we need to find ways to reward them financially, and improve their profitability' (2008: 1). 'Proving' whether a firm as a whole constitutes an 'Inclusive Business' or whether a certain aspect of a firm's operations are 'inclusive' is a critical step in ensuring the right incentives reach the right businesses.

Demonstrating positive development impacts could enable a firm to receive donor support for a business activity (membership to the Business Call to Action network is contingent on reporting), persuade governments to reduce barriers for the establishment of operations in a new country, or improve the image of the business among consumers (to increase profits) and/or local communities (to reduce resistance) or encourage support.

9 It is important to keep in mind that what may generate positive impacts in one situation may not necessarily result in the same benefits in another; however, this is again where a causal chain analysis is instrumental. Identifying all of the assumptions and requirements for an intervention $A$ to generate benefits $B$ can help practitioners better anticipate whether a business activity that empowered women in Ghana will have positive impacts in Bangladesh. 
Demonstrating the impact of a business activity can also be used as evidence for scaling up or replicating Inclusive Business practices by firms, donor agencies, or governments. Unfortunately, such decisions are often made based on evaluations which claim to evaluate impact but do not actually do so. The SNV and WBCSD 'evaluation' of Nestle's Bienestar en Casa programme, for example, states that 'The assessment has assisted Nestle Peru in identifying key success factors to inform the development of the business model and to guide its expansion and replication' (2011: 5). But without reliable information there is the potential to promote practices that aren't actually beneficial, or fail to promote practices that are.

\section{Conclusions}

Businesses have enormous potential to achieve widespread and lasting development impacts (both positive and negative) through their core business models. Despite the understandably growing enthusiasm for the 'Inclusive Business' approach to development, however, donors and development agencies are far from clear about what exactly constitutes 'Inclusive Business'. Partially as a result of this, the majority of Inclusive Business evaluations fail to clearly delineate what business activities are 'inclusive' and also fail to provide a comprehensive and robust analysis of the impact of those activities.

Very few Inclusive Business evaluation methodologies that exist today - either M\&E or impact evaluation - actually directly assess the outcomes and impacts of business activities. M\&E frameworks inherently cannot do so (and many frameworks and studies which claim to be 'Impact Evaluations' are actually M\&E frameworks), and the Impact Evaluations analysed in this paper did not succeed in doing so. They make assumptions that outputs will result in development outcomes without undertaking an analysis of the needs of the communities on which they have an influence, much less thinking through a causal chain.

To accurately assess whether business activities are having a positive impact, the institutions undertaking evaluations should engage in and base their evaluations on a causal chain mapping. For M\&E frameworks, a causal chain analysis will enable practitioners to link the outputs of their activities that they are measuring (e.g. the sale of a product or service) with development impacts that they want to achieve (i.e. improvements in wellbeing), making clear what assumptions are being made about what constitutes inclusiveness, and, critically, by whom.

Because it may not be possible to capture all of the impacts of a business activity or firm, choices need to be made about what can and should be measured. The determination of what to measure and not measure is dependent on who makes those decisions, and has large consequences: a wrong choice could translate to overlooking significant positive or negative impacts, as demonstrated by the evaluations reviewed in this paper.

While M\&E is necessary for tracking and reporting on progress and results, at this nascent stage of 'Inclusive Business,' impact evaluations - which require the establishment of a counterfactual - are also needed. While the construction of a counterfactual can sometimes prove difficult, it is essential in order to gain 
information about the real impacts of a business activity. None of the evaluations reviewed in this paper accounted for what might have happened if the business were not 'inclusive', and therefore did not actually provide information about the impact of those business activities. The evaluations have, however, begun to shed light on the complex network of effects that businesses have in the economic, social, and environmental spheres and the ways in which some firms are attempting to do things that they believe will have positive impacts. As governments, donors, and NGOs devote more resources to facilitating 'Inclusive Business' as a method of achieving development goals (Nelson and Prescott 2008), it is imperative that they have accurate information on which to base these decisions. More, better quality, and less partial evaluations are needed to ascertain the impact of business approaches on development. 


\section{References}

Ashley, C. (2009) 'Harnessing Core Business for Development Impact: Evolving Ideas and Issues for Action', ODI Background Note, London: Overseas

Development Institute (ODI)

_ (2008) 'Measuring the Impact of Business on Development', ODI Opinion, April, London: Overseas Development Institute (ODI)

Ashley, C.; Ellis, K. and Schramm, C. (2009) 'Approaches to Assessing Business Impacts on Development', draft framework paper for 12 May 2009 Meeting Series on Harnessing the Power of the Private Sector for Development, Overseas Development Institute

Banerjee, A. and Duflo, E. (2007) 'The Economic Lives of the Poor', Journal of Economic Perspectives 21.1: 141-67

BIF (Business Innovation Facility Practitioner Hub) (2011) 'What is Inclusive Business', Briefing Note 1, Business Innovation Facility \& Innovations Against Poverty, www.globalhand.org/system/assets/ b60414e3e4b8d043b46c573849258cc53df86912/original/ What_do_we_mean_by_IB_20April2011.pdf?1320206957 (accessed 14 March 2012)

Born, B. and Purcell, M. (2006) 'Avoiding the Local Trap: Scale and Food Systems in Planning Research', Journal of Planning Education and Research 26: 195-207

Bradshaw, S. and Quiros Viquez, A. (2008) 'Women Beneficiaries or Women Bearing the Cost? A Gendered Analysis of the Red de Proteccion Social in Nicaragua', Development and Change 39.5: 823-44

BCtA (Business Call to Action) (2011) Vodafone Expanding Access to Financial Services, www.businesscalltoaction.org/wp-content/ files_mf/1287678958BCtAVodafoneCaseStudyForWeb.pdf (accessed August 2011)

- (2010) Measuring Value of Business Call to Action Initiatives: A Results Reporting Framework, New York: United Nations Development Program

Cartwright, N. (2007) 'Are RCTs the Gold Standard?', BioSocieties 2, London: London School of Economics and Political Science: 11-20

CGD (2006) When Will We Ever Learn?, Report of the Evaluation Gap Working Group, Washington DC: Center for Global Development

Chambers, R. (2004) Ideas for Development: Reflecting Forwards, IDS Working Paper 238, Brighton: IDS

Ellis, K. (2008) 'Is CSR just Corporates Saying the Right Things?', ODI Opinion 100, April

Friedman, M. (1970) 'The Social Responsibility of Business to Increase its Profits', The New York Times Magazine, 13 September 1970 
Garette, B. and Karnani, A. (2010) 'Challenges in Marketing Socially Useful Goods to the Poor', California Management Review 52.4, Berkeley

Gertler, P.; Martinez, S.; Premand, P.; Rawlings, L. and Vermeersch, C. (2011) Impact Evaluation in Practice, Washington DC: The International Bank for Reconstruction and Development/The World Bank

Goetz, A.M. and Gupta, R.S. (1996) 'Who takes the Credit? Gender, Power, and Control over Loan Use in Rural Credit Programs in Bangladesh', World Development 24.1

Gradl, C. and Knobloch, C. (2010) Inclusive Business Guide: How to Develop Business and Fight Poverty, Berlin: Endeva

J-PAL (2011) Program Theory Assessment, www.povertyactionlab.org/methodology/ what-evaluation/program-theory-assessment (accessed July 2011)

Kabeer, N. (1994) Reversed Realities: Gender Hierarchies in Development Thought, Ch. 9, London: Verso Press: 264-305

Kandhker, S.; Koolwal, G. and Samad, H. (2010) Handbook on Impact Evaluation: Quantitative Methods and Practices, Washington DC: The International Bank for Reconstruction and Development/The World Bank

Kapstein, E. (2008) Measuring Unilever's Economic Footprint: The Case of South Africa, London: Unilever

Karlan, D. and Appel, J. (2011) More than Good Intentions: How a New Economics is Helping to Solve Global Poverty, New York: Penguin Group

Karnani, A. (2007) 'The Mirage of Marketing to the Bottom of the Pyramid: How the Private Sector can Help Alleviate Poverty', California Management Review 49.4: $90-111$

Kusek, J.Z. and Rist, R.C. (2004) A Handbook for Development Practitioners: Ten Steps to a Results-Based Monitoring and Evaluation System, Washington DC: World Bank

Nelson, J. and Prescott, D. (2008) Business and the Millennium Development Goals: A Framework for Action, 2nd edition, London: International Business Leaders Forum

Oxfam America, The Coca-Cola Company and SABMiller (2011) Exploring the Links between International Business and Poverty Reduction: The Coca-Cola/ SABMiller Value Chain Impacts in Zambia and El Salvador

Oxfam International (2009) 'Oxfam Poverty Footprint: Understanding Business Contribution to Development', Briefings for Business 4, Oxford: Oxfam International Secretariat

Palmer, G. (2009) The Politics of Breastfeeding: When Breasts are Bad for Business, London: Pinter \& Martin Ltd

Prahalad, C.K. (2004) The Fortune at the Bottom of the Pyramid: Eradicating Poverty through Profits, Philadelphia: Wharton School Publishing 
Ravallion, M. (2001) 'The Mystery of the Vanishing Benefits: An Introduction to Impact Evaluation', The World Bank Economic Review 15.1: 115-40

Retief, M. (2009) Development Sourcing: Small and Local, Ethical Corporation, www.ethicalcorp.com/governance-regulation/development-sourcing-small-and-local (accessed July 2011)

SNV and WBCSD (2011) Nestle Peru and the WBCSD-SNV Alliance for Inclusive Business: 'Bienestar en Casa': Measuring the Impact of an Innovative Distribution Business Model for Nutritional Food in Peru, www.inclusivebusiness.org/nestle_peru_measuring_impact_march2011.pdf (accessed May 2011)

Tanburn, J. (2008) The 2008 Reader on Private Sector Development: Measuring and Reporting Results, Turin, Italy: International Training Centre

Thorbecke, E. (2000) 'The Use of Social Accounting Matrices in Modeling', paper prepared for the 26th General Conference of The International Association for Research in Income and Wealth, Cracow, Poland 2000

UNDP (2008) Creating Value for All: Strategies for Doing Business with the Poor, New York: United Nations Development Programme

UNEP (2009) Towards Triple Impact: Toolbox for Analysing Sustainable Ventures in Developing Countries, United Nations Environment Programme

White, H. (2009) Theory-based Impact Evaluation: Principles and Practice, 3ie Working Paper 3, New Delhi: International Initiative for Impact Evaluation

_ (2007) Evaluating Aid Impact, Research Paper 2007/75, Helsinki, Finland: World Institute for Development Economics Research of the United Nations University (UNU-WIDER)

WBCSD (World Business Council on Sustainable Development) (2011) Unilever in Indonesia: Links between International Business and Poverty Reduction?, www.wbcsd.org/plugins/DocSearch/details.asp?type=DocDet\&Objectld=MTc5Njg (accessed May 2011)

(2008) WBCSD Measuring Impact Framework - Version 1.0, World Business Council on Sustainable Development and International Finance Corporation, World Bank Group

WBCSD and SNV (2011) Inclusive Business: Creating Value in Latin America, World Business Council for Sustainable Development and SNV Development Organisation 